Journal of Organometallic Chemistry, 371 (1989) 383-392

Elsevier Sequoia S.A., Lausanne - Printed in The Netherlands

JOM 09877

\title{
Reinvestigation of the reaction of acid chloride with Wilkinson's catalyst: crystal and molecular structure of cis- $\mathrm{RhCl}_{2}\left(\mathrm{PPh}_{3}\right)_{2}\left(\mathrm{COC}_{2} \mathrm{H}_{5}\right)$ complex
}

\author{
Ju-Yeh Shie, Ying-Chih Lin ${ }^{\star}$, and Yu Wang \\ Department of Chemistry, National Taiwan University, Taipei, (Taiwan, R.O.C.)
}

(Received November 28th, 1988; in revised form February 18th, 1989)

\begin{abstract}
The interactions of Wilkinson's catalyst $\mathrm{RhCl}\left(\mathrm{PPh}_{3}\right)_{3}(\mathbf{1})$ with some acid chlorides are reported. The less known cis-complex obtained directly from oxidative addition is the subject of this study. Reaction of $\mathrm{CH}_{3} \mathrm{CHClC}(\mathrm{O}) \mathrm{Cl}$ with 1 initially gives the cis- $\mathrm{Rh}$ (III) acyl complex, $\mathbf{R h C l}_{2}\left(\mathbf{P P h}_{3}\right)_{2}\left(\mathrm{COCHClCH}_{3}\right)$ (cis-2d), which then transforms to the corresponding trans-isomer. The ${ }^{31} \mathrm{P}$ NMR spectra of this cis-complex show the virtual coupling for the two magnetically inequivalent $\mathbf{P P h}_{3}$ ligands with the coupling constant of $15 \mathrm{~Hz}$. No such virtual coupling was observed in the trans-isomer. Another five-coordinated cis-complex $\mathrm{Cl}_{2} \mathrm{Rh}\left(\mathrm{COC}_{2} \mathrm{H}_{5}\right)\left(\mathrm{PPh}_{3}\right)_{2}$ was isolated from the reaction of $\mathrm{CH}_{3} \mathrm{CH}_{2} \mathrm{COCl}$ with 1 at low temperature and its crystal structure has also been determined. The cis-complex crystallizes in the monoclinic space group $P 2_{1} / c$ in a cell having dimensions of $a=13.329(3)$, $b=14.644(3) c=19.712(3) \AA$ and $\beta=99.52(1)^{\circ}$. Some 2954 unique reflections with $I>2.5 \sigma(I)$ were used in the refinement to give final discrepancy indices of $R=0.045$ and $R_{\mathrm{w}}=0.038$. The shortest $\mathrm{Rh}-\mathrm{C}$ separation $1.95(1) \AA$, known for a single bond, might be the reason why the isolation and crystallization of this complex is possible.
\end{abstract}

\section{Introduction}

The Wilkinson catalyst is effective in the decarbonylation of aldehydes [1] and acid halides [2] which is a useful and important synthetic method for organic compounds. There are some reports on the decarbonylations catalyzed by $\mathrm{RhCl}\left(\mathrm{PPh}_{3}\right)_{3}$ under relatively mild conditions. Various products are observed when differing acid chlorides or aldehydes are used. An olefin is the product if the acid halide or aldehyde has a $\beta$-hydrogen. If the aldehyde or acid chloride has no $\beta$-hydrogen the alkane or alkyl chloride is the product of the decarbonylation. 
The mechanism of the decarbonylation [3] has been proposed as follows:

$\mathrm{RhCl}\left(\mathrm{PPh}_{3}\right)_{3} \rightleftharpoons \mathrm{RhCl}\left(\mathrm{PPh}_{3}\right)_{2}+\mathbf{P P h}_{3}$

$\mathrm{RhCl}\left(\mathrm{PPh}_{3}\right)_{2}+\mathrm{RCOCl} \rightarrow$ cis- $\mathrm{RhCl}_{2}\left(\mathrm{PPh}_{3}\right)_{2}(\mathrm{COR})$

(cis-2)

cis $-\mathrm{RhCl}_{2}\left(\mathrm{PPh}_{3}\right)_{2}(\mathrm{COR}) \rightarrow$ trans- $\mathrm{RhCl}_{2}\left(\mathrm{PPh}_{3}\right)_{2}(\mathrm{COR})$

(trans-2)

trans- $\mathrm{RhCl}_{2}\left(\mathrm{PPh}_{3}\right)_{2}(\mathrm{COR}) \rightarrow \mathrm{RhCl}_{2}\left(\mathrm{PPh}_{3}\right)_{2}(\mathrm{CO}) \mathrm{R}$

The stoichiometric decarbonylation reaction begins with the oxidative addition of acid chloride to $\mathrm{RhCl}\left(\mathrm{PPh}_{3}\right)_{2}$ to afford a cis- $\mathrm{RhCl}_{2}\left(\mathrm{PPh}_{3}\right)_{2}(\mathrm{COR})$, followed by the conversion of the cis-isomer to the trans-isomer. However, it was not certain in complexes with $\mathrm{PPh}_{3}$ ligands, whether the migration of the carbonyl group to form the alkyl complex occurs exclusively from the trans-isomer. Recently, Pignolet and co-workers were able to isolate a cis-Rh(III) acyl complex by use of a chelating phosphine ligand but found no decarbonylation ability by such a cis-complex even upon warming to $190^{\circ} \mathrm{C}$ [4]. However, for a complex without chelating ligand, the detailed structure of cis-/trans-isomers remains somewhat clouded. Preliminary results from single crystal $\mathrm{X}$-ray structural determinations of the intermediates are not in agreement. $\mathrm{RhCl}_{2}\left(\mathrm{COCH}_{2} \mathrm{CH}_{2} \mathrm{Ph}\right)\left(\mathrm{PPh}_{3}\right)_{2}$ [5] is reported to have a square pyramidal geometry, whereas $\mathrm{RhCl}_{2}\left(\mathrm{COCH}_{2} \mathrm{Ph}\right)\left(\mathrm{PPh}_{3}\right)_{2}$ [6] is reported to have a trigonal bipyramidal structure. The structure assignments were made in the preliminary states of refinement and as such are subject to significant uncertainty. In this study, we explore the initial step of the decarbonylation of acid chlorides in the presence of the Wilkinson catalyst. A kinetically labile cis- $\mathrm{RhCl}_{2}\left(\mathrm{PPh}_{3}\right)_{2}\left(\mathrm{COC}_{2} \mathrm{H}_{5}\right)$ complex was isolated at low temperature and fully characterized by single crystal $\mathrm{X}$-ray diffraction study.

\section{Experimental}

\section{General}

The ${ }^{1} \mathrm{H}$ and ${ }^{31} \mathrm{P}$ NMR spectra were recorded on a Bruker AM-300WB FT NMR spectrometer using 5-mm NMR tubes. ${ }^{31} \mathrm{P}$ NMR spectra of Rh-phosphine complexes were recorded with broadband proton decoupling in the composite pulse decoupling mode. Infrared spectra were recorded on a Perkin-Elmer $983 \mathrm{G}$ Infrared spectrometer in solution cells equipped with calcium fluoride windows and $0.5 \mathrm{~mm}$ path length. All air-sensitive compounds were manipulated in a nitrogen-filled dry glovebox (VAC HE-63-P) or handled by use of Schlenk techniques. Chloroacetyl chloride, acetyl chloride, propionyl chloride and 2-chloropropionyl chloride were obtained from Merck. THF was dried by refluxing with $\mathrm{Na}$ /benzophenone under nitrogen before use. $\mathrm{CH}_{2} \mathrm{Cl}_{2}$ and $\mathrm{n}$-hexane were freshly distilled from calcium hydride under nitrogen. $\mathbf{P} \mathbf{P h}_{3}$ was recrystallized from ethanol.

\section{Reactions}

Wilkinson's catalyst, $\mathrm{RhCl}\left(\mathrm{PPh}_{3}\right)_{3}$ (1) [7] was prepared by a published method. ${ }^{31} \mathrm{P}$ NMR: $52.9 \mathrm{ppm}\left(\mathrm{dt}, J_{\mathrm{Rh}-\mathrm{P}}=189 \mathrm{~Hz}, J_{\mathrm{P}-\mathrm{P}}=37.5 \mathrm{~Hz}\right), 35.9 \mathrm{ppm}\left(\mathrm{dd}, J_{\mathrm{Rh}-\mathrm{P}}=\right.$ 
$139 \mathrm{~Hz}, J_{\mathrm{P}-\mathrm{P}}=37.5 \mathrm{~Hz}$ ). The phosphine trans to the chloride gives a peak at lower field than the mutually trans phosphine ligands. The values of $J_{\mathrm{Rh}-\mathrm{P}}$ for the phosphine trans to the chloride are much greater than for the mutually trans ones.

Reactions of 1 with acid halides. Typically, a solution of ca. $30 \mathrm{mg}$ complex 1 $(0.03 \mathrm{mmol})$ was mixed with $5-10 \mu 1$ of acid chloride to make a total volume of ca. $0.6 \mathrm{ml} \mathrm{CDCl}{ }_{3}$ solution in an NMR tube at $0^{\circ} \mathrm{C}$ and the reaction was then monitored by ${ }^{1} \mathrm{H}$ and ${ }^{31} \mathrm{P}$ NMR spectroscopy at room temperature as a function of time.

NMR spectroscopy of the reactions of acetyl and propionyl chloride with 1 gives the same results as those obtained by Wilkinson et al.; namely, at room temperature, the reaction of $\mathrm{CH}_{3} \mathrm{COCl}$ with 1 proceeds with the formation of the 5-coordinate cis-acyl isomer, ${ }^{1} \mathrm{H}$ NMR: $3.37(\mathrm{~s}) ;{ }^{31} \mathrm{P}$ NMR: $29.8\left(\mathrm{~d}, J_{\mathrm{Rh}-\mathrm{P}}=145 \mathrm{~Hz}\right)$, then the trans-acyl isomer, ${ }^{1} \mathrm{H}$ NMR: $2.49(\mathrm{~s}),{ }^{31} \mathrm{P}$ NMR: $23.6\left(\mathrm{~d}, J_{\mathrm{Rh}-\mathrm{P}}=108 \mathrm{~Hz}\right)$, and finally an equilibrium mixture of the trans-isomer with the decarbonylation product $\mathrm{RhCl}_{2}\left(\mathrm{PPh}_{3}\right)_{2}\left(\mathrm{CH}_{3}\right),{ }^{1} \mathrm{H}$ NMR: $0.08\left(\mathrm{~m}, J_{\mathrm{RH}-\mathrm{H}}=1.9 \mathrm{~Hz}, J_{\mathrm{P}-\mathrm{H}}=4.8 \mathrm{~Hz}\right) ;{ }^{31} \mathrm{P}$ NMR: $18.5\left(\mathrm{~d}, J_{\mathrm{Rh}-\mathrm{P}}=90 \mathrm{~Hz}\right)$. For $\mathrm{CH}_{3} \mathrm{CH}_{2} \mathrm{COCl}$, no alkyl complex was observed at room temperature, i.e. after $7 \mathrm{~h}$, an equilibrium mixture of $c i s$-isomer, ${ }^{1} \mathrm{H}$ NMR: $4.03\left(\mathrm{q}, J_{\mathrm{H}-\mathrm{H}}=7.2 \mathrm{~Hz}\right), 1.17(\mathrm{t}) ;{ }^{31} \mathrm{P}$ NMR: $30.3\left(\mathrm{~d}, J_{\mathrm{Rh}-\mathrm{P}}=146 \mathrm{~Hz}\right)$, and trans-isomers, ${ }^{1} \mathrm{H}$ NMR: $2.98\left(\mathrm{q}, J_{\mathrm{H}-\mathrm{H}}=7.2 \mathrm{~Hz}, \mathrm{CH}_{2}\right), 0.08\left(\mathrm{t}, \mathrm{CH}_{3}\right) ;{ }^{31} \mathrm{P}$ NMR: $23.6\left(\mathrm{~d}, J_{\mathrm{Rh}-\mathrm{P}}=111 \mathrm{~Hz}\right)$, was obtained. This solution was dried under vacuum and redissolved in $\mathrm{CH}_{2} \mathrm{Cl}_{2}$ for growing single crystals of the cis-isomer. Since our interest is in the cis-isomer, no heating was applied to cause decarbonylation.

For chloroacetyl chloride, the signals from the cis-complex $\mathrm{RhCl}_{2}\left(\mathrm{PPh}_{3}\right)_{2}(\mathrm{CO}$ $\left.\mathrm{CH}_{2} \mathrm{Cl}\right),{ }^{1} \mathrm{H}$ NMR: 5.35 (s); ${ }^{31}$ P NMR: $29.9\left(\mathrm{~d}, J_{\mathrm{Rh}-\mathrm{P}}=139 \mathrm{~Hz}\right)$, are observed in the NMR spectrum as soon as the two components are mixed. NMR monitoring of the initial stage of the reaction, reveals the formation of a six-coordinate complex $\mathrm{RhCl}_{2}(\mathrm{CO})\left(\mathrm{PPh}_{3}\right)_{3}\left(\mathrm{CH}_{2} \mathrm{Cl}\right),{ }^{1} \mathrm{H}$ NMR: $3.71\left(\mathrm{dt}, J_{\mathrm{P}-\mathrm{H}}=6.3 \mathrm{~Hz}, J_{\mathrm{Rh}-\mathrm{H}}=2.7 \mathrm{~Hz}\right)$; ${ }^{31} \mathrm{P}$ NMR: $17.7 \mathrm{ppm}\left(\mathrm{d}, J_{\mathrm{Rh}-\mathrm{P}}=90 \mathrm{~Hz}\right)$, without detection of the corresponding trans-complex. Only once the reaction had gone to about $75 \%$ completion, was a trace amount of the trans-complex detected. ${ }^{31} \mathrm{P}$ NMR: $22.4 \mathrm{ppm}\left(\mathrm{d}, J_{\mathrm{Rh}-\mathrm{P}}=102\right.$ Hz).

When $\mathrm{CH}_{3} \mathrm{CHClCOCl}$ was mixed with 1 , oxidative addition of the acid chloride immediately gave the 5-coordinated cis- $\mathrm{Rh}$ acyl complex which exhibits two doublets of doublet pairs in its ${ }^{31} \mathrm{P}$ NMR spectrum, ${ }^{1} \mathrm{H}$ NMR: $5.94\left(\mathrm{q}, J_{\mathrm{H}-\mathrm{H}}=7.2 \mathrm{~Hz}\right.$ ), 1.40 (d); ${ }^{31}$ P NMR: 28.7 (dd, $\left.J_{\mathrm{Rh}-\mathrm{P}}=139 \mathrm{~Hz}, J_{\mathrm{P}-\mathrm{P}}=15 \mathrm{~Hz}\right), 25.5\left(\mathrm{dd}, J_{\mathrm{Rh}-\mathrm{P}}=139\right.$ $\left.\mathrm{Hz}, J_{\mathrm{P}-\mathrm{P}}=15 \mathrm{~Hz}\right)$. The trans-isomer, ${ }^{1} \mathrm{H}$ NMR: $4.63\left(\mathrm{q}, J_{\mathrm{H}-\mathrm{H}}=7.3 \mathrm{~Hz}\right), 0.76$ (d); ${ }^{31} \mathrm{P}$ NMR: $22.7\left(\mathrm{~d}, J_{\mathrm{Rh}-\mathrm{P}}=106 \mathrm{~Hz}\right)$, began to form after about an hour and after 12 $h$ the cis- and trans-isomers were present in a ratio of $1: 9$. No virtual $P_{-} \mathbf{P}$ coupling was detected for the trans-isomer. At room temperature, no decarbonylation product was detected in the NMR spectrum as was the the case for $\mathrm{CH}_{3} \mathrm{CH}_{2} \mathrm{COCl}$. No heat was applied to cause decarbonylation.

\section{Crystal structure determination}

Crystals suitable for single crystal $\mathrm{X}$-ray analysis were obtained by slow evaporation from a $\mathrm{CH}_{2} \mathrm{Cl}_{2}$ solution containing an equilibrium mixture of cis- and trans-isomers of $\mathrm{RhCl}_{2}\left(\mathrm{PPh}_{3}\right)_{2}(\mathrm{COEt})$ in a freezer at $-20^{\circ} \mathrm{C}$. It seems that it is easier for the cis-isomer to form single crystals. Crystals of cis$\mathrm{RhCl}_{2}\left(\mathrm{COC}_{2} \mathrm{H}_{5}\right)\left(\mathrm{PPh}_{3}\right)_{2}$ are monoclinic with $a=13.329(3), \quad b=14.644(3) c=$ 
Table 1

Crystal and intensity collection data for cis- $\mathrm{Rh}\left(\mathrm{PPh}_{3}\right)_{2}\left(\mathrm{COCH}_{2} \mathrm{CH}_{3}\right) \mathrm{Cl}_{2}$ (at room temperature)

\begin{tabular}{ll}
\hline mol formula & $\mathrm{C}_{39} \mathrm{H}_{35} \mathrm{OCl}_{2} \mathrm{P}_{2} \mathrm{Rh}$ \\
space group & $P 2{ }_{1} / c$ \\
$a, \AA$ & $13.329(3)$ \\
$b, \AA$ & $14.644(3)$ \\
$c, \AA$ & $19.712(3)$ \\
$\beta$, deg & $99.52(1)$ \\
$V, \AA^{3}$ & 3794.72 \\
radiation Mo- $K_{\alpha}$ & $\lambda=0.7107 \AA$ \\
$2 \theta$ range & $2^{\circ}-50^{\circ}$ \\
scan speed, deg/min & $20 / 2-20 / 13$ \\
scan type & $2 \theta / \omega$ \\
scan width & $2(0.8+0.35 \tan \theta)$ \\
total no. of reflections & 6969 \\
no. of unique reflections with $I>2.5 \sigma(I)$ & 2954 \\
standard reflections & $(-2,2,-7)$ \\
& $(2,2,7)$ \\
$R$ & $(2,-2,7)$ \\
$R_{w}$ & 0.045 \\
\hline
\end{tabular}

19.712(3) $\AA$ and $\beta=99.52(1)^{\circ}$ as determined from a least-squares refinement of the angular settings of 25 reflections centered accurately on an Enraf-Nonius CAD4 diffractometer. Successful solution and refinement was achieved when the centric space group $P 2_{1} / c(Z=4)$ was used. A total of 6969 unique reflections were

Table 2

${ }^{1} \mathrm{H}$ and ${ }^{31} \mathrm{P}$ NMR data for $\mathrm{RhCl}_{2} \mathrm{~L}_{2}(\mathrm{COR})$ and $\mathrm{RhCl}_{2} \mathrm{~L}_{2}(\mathrm{CO}) \mathrm{R}$

\begin{tabular}{lll}
\hline Complex & ${ }^{1} \mathrm{H}$ NMR & ${ }^{31} \mathrm{P} \mathrm{NMR}$ \\
\hline cis-2a & $3.37(\mathrm{~s})$ & $29.8\left(\mathrm{~d}, J_{\mathrm{Rh}-\mathrm{P}}=145 \mathrm{~Hz}\right)$ \\
trans-2a & $2.49(\mathrm{~s})$ & $23.6\left(\mathrm{~d}, J_{\mathrm{Rh}-\mathrm{P}}=108 \mathrm{~Hz}\right)$ \\
3a & $0.08(\mathrm{~m})$ & $18.5\left(\mathrm{~d}, J_{\mathrm{Rh}-\mathrm{P}}=90 \mathrm{~Hz}\right)$ \\
& $\left(J_{\mathrm{Rh}-\mathrm{H}}=1.9 \mathrm{~Hz}\right)$ & \\
& $\left(J_{\mathrm{P}-\mathrm{H}}=4.8 \mathrm{~Hz}\right)$ & \\
cis-2b & $5.35(\mathrm{~s})$ & $29.9\left(\mathrm{~d}, J_{\mathrm{Rh}}=139 \mathrm{~Hz}\right)$ \\
trans-2b & - & $22.4\left(\mathrm{~d}, J_{\mathrm{Rh}-\mathrm{P}}=102 \mathrm{~Hz}\right)$ \\
3b & $3.71(\mathrm{dt})$ & $17.7\left(\mathrm{~d}, J_{\mathrm{Rh}-\mathrm{P}}=90 \mathrm{~Hz}\right)$ \\
& $\left(J_{\mathrm{P}-\mathrm{H}}=6.3 \mathrm{~Hz}\right)$ & \\
& $\left(J_{\mathrm{Rh}-\mathrm{P}}=2.7 \mathrm{~Hz}\right)$ & \\
cis-2c & $4.03(\mathrm{q}), 1.17(\mathrm{t})$ & $30.3\left(\mathrm{~d}, J_{\mathrm{Rh}-\mathrm{P}}=146 \mathrm{~Hz}\right)$ \\
& $\left(J_{\mathrm{H}-\mathrm{H}}=7.2 \mathrm{~Hz}\right)$ & \\
trans-2c & $2.98(\mathrm{q}), 0.08(\mathrm{t})$ & $23.6\left(\mathrm{~d}, J_{\mathrm{Rh}-\mathrm{P}}=111 \mathrm{~Hz}\right)$ \\
& $\left(J_{\mathrm{H}-\mathrm{H}}=7.2 \mathrm{~Hz}\right)$ & \\
cis-2d & $5.94(\mathrm{q}), 1.40(\mathrm{~d})$ & $28.7\left(\mathrm{dd}, J_{\mathrm{Rh}-\mathrm{P}}=139 \mathrm{~Hz}\right)$ \\
& $\left(J_{\mathrm{H}-\mathrm{H}}=7.2 \mathrm{~Hz}\right)$ & $\left(J_{\mathrm{P}-\mathrm{P}}=15 \mathrm{~Hz}\right)$ \\
& & $25.5\left(\mathrm{dd}, J_{\mathrm{Rh}-\mathrm{P}}=139 \mathrm{~Hz}\right)$ \\
& & $\left(J_{\mathrm{P}-\mathrm{P}}=15 \mathrm{~Hz}\right)$ \\
trans-2d & $4.63(\mathrm{q}), 0.76(\mathrm{~d})$ & $22.7\left(\mathrm{~d}, J_{\mathrm{Rh}-\mathrm{P}}=106 \mathrm{~Hz}\right)$ \\
& $\left(J_{\mathrm{H}-\mathrm{H}}=7.2 \mathrm{~Hz}\right)$ & \\
\hline
\end{tabular}


measured in the scan range $2 \theta=2-50^{\circ}$ using graphite monochromatized Mo-K $K_{\alpha}$ radiation (Mo- $K_{\alpha}, \lambda=0.7107 \AA$ ) and employing a variable rate $\omega-2 \theta$ scan technique. No decay was noted in the intensities of three standard reflections recorded after every 7300 sec. After correction for Lorentz, polarization, absorption and

Table 3

Atomic coordinate and isotropic thermal parameters for nonhydrogen atoms of cis-2c

\begin{tabular}{|c|c|c|c|c|}
\hline Atom & $x$ & $y$ & $z$ & $B_{\text {iso }}$ \\
\hline $\mathbf{R h}$ & $0.27555(6)$ & $0.11217(6)$ & $0.23281(4)$ & $2.34(3)$ \\
\hline $\mathrm{Cl}(1)$ & $0.43056(20)$ & $0.05806(19)$ & $0.20257(14)$ & $3.50(12)$ \\
\hline $\mathrm{Cl}(2)$ & $0.24469(23)$ & $0.17897(20)$ & $0.12181(14)$ & $3.98(14)$ \\
\hline$C(1)$ & $0.1841(8)$ & $0.0074(7)$ & $0.2168(5)$ & $3.0(5)$ \\
\hline$C(2)$ & $0.1955(8)$ & $-0.0439(8)$ & $0.1524(6)$ & $4.3(6)$ \\
\hline$C(3)$ & $0.1244(12)$ & $-0.1136(11)$ & $0.1312(7)$ & $9.8(11)$ \\
\hline $\mathbf{O}(1)$ & $0.1233(5)$ & $-0.0157(5)$ & $0.2519(3)$ & $4.1(4)$ \\
\hline$P(1)$ & $0.34369(20)$ & $0.05937(18)$ & $0.34167(13)$ & $2.37(12)$ \\
\hline$P(2)$ & $0.14730(20)$ & $0.20950(18)$ & $0.25313(14)$ & $2.55(12)$ \\
\hline $\mathrm{C}(11)$ & $0.3779(7)$ & $-0.0631(6)$ & $0.3509(5)$ & $2.5(5)$ \\
\hline $\mathrm{C}(12)$ & $0.3883(9)$ & $-0.1183(7)$ & $0.2963(5)$ & $3.9(6)$ \\
\hline$C(13)$ & $0.4159(10)$ & $-0.2100(7)$ & $0.3073(6)$ & $4.9(7)$ \\
\hline$C(14)$ & $0.4345(9)$ & $-0.2450(7)$ & $0.3714(6)$ & $4.5(6)$ \\
\hline$C(15)$ & $0.4255(9)$ & $-0.1907(7)$ & $0.4264(5)$ & $4.1(6)$ \\
\hline$C(16)$ & $0.3978(7)$ & $-0.1000(7)$ & $0.4165(5)$ & $3.2(5)$ \\
\hline$C(21)$ & $0.4627(7)$ & $0.1215(7)$ & $0.3639(5)$ & $2.8(5)$ \\
\hline$C(22)$ & $0.4607(8)$ & $0.2144(7)$ & $0.3588(5)$ & $3.6(5)$ \\
\hline$C(23)$ & $0.5502(10)$ & $0.2649(8)$ & $0.3721(5)$ & $4.7(6)$ \\
\hline$C(24)$ & $0.6404(9)$ & $0.2235(8)$ & $0.3913(6)$ & $4.8(6)$ \\
\hline$C(25)$ & $0.6433(8)$ & $0.1307(9)$ & $0.3976(6)$ & $4.8(7)$ \\
\hline$C(26)$ & $0.5551(8)$ & $0.0786(7)$ & $0.3832(5)$ & $3.7(5)$ \\
\hline$C(31)$ & $0.2811(7)$ & $0.0736(7)$ & $0.4172(5)$ & $2.8(5)$ \\
\hline$C(32)$ & $0.3276(8)$ & $0.1203(8)$ & $0.4758(5)$ & $3.8(5)$ \\
\hline$C(33)$ & $0.2863(9)$ & $0.1176(9)$ & $0.5360(5)$ & $4.8(6)$ \\
\hline$C(34)$ & $0.1995(10)$ & $0.0688(9)$ & $0.5375(6)$ & $5.6(7)$ \\
\hline$C(35)$ & $0.1524(9)$ & $0.0219(8)$ & $0.4793(6)$ & $4.6(6)$ \\
\hline$C(36)$ & $0.1909(8)$ & $0.0250(7)$ & $0.4189(5)$ & $3.5(5)$ \\
\hline$C(41)$ & $0.1996(8)$ & $0.3252(7)$ & $0.2575(5)$ & $3.2(5)$ \\
\hline$C(42)$ & $0.1503(8)$ & $0.3999(8)$ & $0.2837(6)$ & $4.3(6)$ \\
\hline$C(43)$ & $0.1943(9)$ & $0.4857(8)$ & $0.2873(7)$ & $5.4(7)$ \\
\hline$C(44)$ & $0.2850(10)$ & $0.5005(8)$ & $0.2678(7)$ & $5.6(7)$ \\
\hline$C(45)$ & $0.3351(9)$ & $0.4301(8)$ & $0.2442(6)$ & $4.7(6)$ \\
\hline$C(46)$ & $0.2933(8)$ & $0.3425(7)$ & $0.2383(5)$ & $3.3(5)$ \\
\hline$C(51)$ & $0.0876(8)$ & $0.1995(7)$ & $0.3286(5)$ & $3.0(5)$ \\
\hline $\mathrm{C}(52)$ & $-0.0003(8)$ & $0.1485(7)$ & $0.3264(5)$ & $3.9(6)$ \\
\hline$C(53)$ & $-0.0507(9)$ & $0.1427(8)$ & $0.3818(7)$ & $5.6(7)$ \\
\hline$C(54)$ & $-0.0119(10)$ & $0.1893(8)$ & $0.4424(6)$ & $5.6(7)$ \\
\hline$C(55)$ & $0.0752(9)$ & $0.2382(8)$ & $0.4456(6)$ & $4.8(6)$ \\
\hline$C(56)$ & $0.1252(8)$ & $0.2433(7)$ & $0.3908(5)$ & $3.5(5)$ \\
\hline$C(61)$ & $0.0323(7)$ & $0.2142(7)$ & $0.1864(5)$ & $3.0(5)$ \\
\hline$C(62)$ & $-0.0374(9)$ & $0.2818(8)$ & $0.1879(6)$ & $5.4(7)$ \\
\hline$C(63)$ & $-0.1294(9)$ & $0.2830(9)$ & $0.1431(7)$ & $5.8(7)$ \\
\hline$C(64)$ & $-0.1473(9)$ & $0.2174(9)$ & $0.0929(6)$ & $5.4(7)$ \\
\hline$C(65)$ & $-0.0774(9)$ & $0.1511(8)$ & $0.0904(6)$ & $5.3(6)$ \\
\hline$C(66)$ & $0.0111(8)$ & $0.1482(8)$ & $0.1370(6)$ & $4.4(6)$ \\
\hline
\end{tabular}


background effects, 2954 reflections were judged observed $(I>2.5 \sigma(I))$ and were used in all the subsequent calculations. A three dimensional Patterson function revealed the positions of the rhodium atom. Fourier and difference Fourier analysis revealed the positions of all the remaining nonhydrogen atoms. Full matrix leastsquares refinement, with all nonhydrogen atoms being refined anistropically, converged to final $R$ and $R_{\mathrm{w}}$ values of 0.045 and 0.038 respectively. Data collection parameters are summarized in Table 1, NMR data are listed in Table 2, and the final values of the positional and the isotropic thermal parameters are given in Table 3. Scattering factors and anomalous dispersion terms were taken from the literature [8].

\section{Results and discussion}

\section{Decarbonylation in the presence of Wilkinson's catalyst}

Acid halides, including $\mathrm{CH}_{3} \mathrm{COCl}, \mathrm{CH}_{3} \mathrm{CH}_{2} \mathrm{COCl}, \mathrm{ClCH}_{2} \mathrm{COCl}$ and $\mathrm{CH}_{3} \mathrm{CHClCOCl}$ were allowed to react with Wilkinson's catalyst $\mathrm{RhCl}\left(\mathrm{PPh}_{3}\right)_{3}(1)$ in $\mathrm{CDCl}_{3}$ at room temperature. These reactions were monitored by ${ }^{31} \mathrm{P}$ and ${ }^{1} \mathrm{H}$ NMR spectroscopy. A 14-electron species, $\mathrm{RhCl}\left(\mathrm{PPh}_{3}\right)_{2}$, has been proposed as a solvent-stabilized, and very reactive intermediate in reactions involving Wilkinson's catalyst [9]. Oxidative addition of an acid halide to $\mathrm{RhCl}\left(\mathrm{PPh}_{3}\right)_{2}$ initiates the stoichiometric decarbonylation. This very first step probably yields a 5-coordinate acyl complex with two $\mathbf{P P h}_{3}$ ligands in cis configuration. Trigonal bipyramidal (TBP) and square pyramidal (SP) are two commonly observed geometries for complexes with 5-coordination. From the structure determination of $\mathrm{RhCl}_{2}\left(\mathrm{PPh}_{3}\right)_{2}(\mathrm{COEt})$ described below, it is reasonable to assume that the acetyl complex also possesses SP geometry with the acetyl ligand occupying the apical position. The acyl complex isomerizes from a cis-form to a trans-form which shows peaks at different chemical shifts and with different coupling constants in their respective ${ }^{1} \mathrm{H}$ and ${ }^{31} \mathrm{P}$ NMR spectra. In addition, in the infrared spectra, absorptions in the $\mathrm{Rh}-\mathrm{Cl}$ and carbonyl regions of the cis-isomer are also different from those of the trans-isomer [10]. The 5-coordinate acyl complex possesses an open coordinate site that facilitates alkyl migration. Finally, the alkyl complex undergoes intramolecular reductive elimination to yield a chloroalkane and $\mathrm{RhCl}(\mathrm{CO})\left(\mathrm{PPh}_{3}\right)_{2}$. An alkyl group bearing a $\beta$-hydrogen probably undergoes elimination to give olefin and hydrogen chloride.

\section{Interaction of various acid chlorides with 1}

For the reaction of acetyl chloride with 1. Baird and co-workers [5] have proposed the reaction pathway mentioned above, namely, the formation of an unstable cis-acetyl complex, $\mathrm{RhCl}_{2}\left(\mathrm{PPh}_{3}\right)_{2}(\mathrm{COMe})$ (cis-2a) which is followed by its isomerization at room temperature to another acyl complex, trans-2a. Then a six-coordinate complex $\mathrm{RhCl}_{2}\left(\mathrm{PPh}_{3}\right)_{2}(\mathrm{CO})(\mathrm{Me})$ (3a) forms and establishes an equilibrium with trans-2a. For the reaction of $\mathrm{CH}_{2} \mathrm{ClCOCl}$, Baird [10] had reported the isolation of $\mathrm{RhCl}_{2}(\mathrm{CO})\left(\mathrm{PPh}_{3}\right)_{2}\left(\mathrm{CH}_{2} \mathrm{Cl}\right)(3 \mathrm{~b})$ obtained directly from the reaction of $\mathrm{ClCH}_{2} \mathrm{COCl}$ with 1 in refluxing $\mathrm{CH}_{2} \mathrm{Cl}_{2}$. In our experiment, cis$\mathrm{RhCl}_{2}\left(\mathrm{PPh}_{3}\right)_{2}\left(\mathrm{COCH}_{2} \mathrm{Cl}\right)$ (cis-2b) could be observed in the initial stage provided the solution was not heated. Complex cis-2b exhibits a resonance at $5.34 \mathrm{ppm}$ for $\mathrm{CH}_{2}$ group in its ${ }^{1} \mathrm{H}$ NMR spectrum, and a doublet peak at $29.9 \mathrm{ppm}\left(J_{\mathrm{Rh}-\mathrm{P}}=140\right.$ 
$\mathrm{Hz}$ ) for $\mathrm{PPh}_{3}$ in the ${ }^{31} \mathrm{P}$ NMR spectrum. Alkyl migration occurred in about $10 \mathrm{~min}$ while only a trace amount of trans-2b was detected by ${ }^{31} \mathbf{P}$ NMR. The existence of complex trans-2 was later confirmed by a weak doublet peak at $22.4 \mathrm{ppm}$ in the ${ }^{31} \mathbf{P}$ NMR spectrum after $2 \mathrm{~h}$. It is reasonable to assume that the decarbonylation step involves the intermediate trans-2b, which is less stable than trans-2a.

Wilkinson and co-workers [11] have described the reaction of excess $\mathrm{CH}_{3} \mathrm{CH}_{2} \mathrm{COCl}$ with 1 in refluxing $\mathrm{CH}_{2} \mathrm{Cl}_{2}$. After some solvent had been removed rapidly from and diethyl ether added to the concentrated solution, trans$\mathrm{RhCl}_{2}\left(\mathrm{PPh}_{3}\right)_{2}(\mathrm{COEt})$ (trans-2c) was obtained as a solid which gave a quartet / triplet pair at $2.98 / 0.78 \mathrm{ppm}$ in the ${ }^{1} \mathrm{H}$ NMR spectrum. In our experiment, when $\mathrm{EtCOCl}$ was added to a solution of $\mathrm{RhCl}\left(\mathrm{PPh}_{3}\right)_{3}$ in $\mathrm{CDCl}_{3}$ at room temperature, another quartet/triplet pair at $4.03 / 1.17 \mathrm{ppm}$ with $J_{\mathrm{H}-\mathrm{H}}=7.3 \mathrm{~Hz}$ was observed in the initial stage. The corresponding ${ }^{31} \mathrm{P}$ NMR signal appeared as a doublet at $35.9 \mathrm{ppm}$ with $J_{\mathrm{Rh}-\mathrm{P}}=146 \mathrm{~Hz}$. This is assigned to the cis- $\mathrm{RhCl}_{2}\left(\mathrm{PPh}_{3}\right)_{2}(\mathrm{COEt})(\mathrm{cis}-2 \mathrm{c})$. Later, the 2.98/0.78 ppm quartet/triplet pair appeared. These signals can be assigned to the complex trans-2c which shows peaks at $29.24 \mathrm{ppm}$ with $J_{\mathrm{Rh}-\mathrm{P}}=111$ $\mathrm{Hz}$ in the ${ }^{31} \mathrm{P} \mathrm{NMR}$ spectrum. The peak attributed to the $\mathrm{RhCl}_{2}\left(\mathrm{PPh}_{3}\right)_{2}(\mathrm{CO})(\mathrm{Et})$ complex was not detected during the course of reaction at room temperature during about $7 \mathrm{~h}$.

It is expected that when $\mathrm{CH}_{3} \mathrm{CHClCOCl}$ reacts with 1 , the resonances of the cisand trans-acyl complexes on the ${ }^{31} \mathrm{P}$ NMR spectrum should appear as doublets in the region of 29 and 22 ppm respectively. But upon mixing $\mathrm{CH}_{3} \mathrm{CHClCOCl}$ with $\mathrm{RhCl}\left(\mathrm{PPh}_{3}\right)_{3}$ in $\mathrm{CDCl}_{3}$, two doublets of doublet peaks appeared at $28.7\left(J_{\mathrm{Rh}-\mathrm{P}}=\right.$ $139 \mathrm{~Hz})$ and $25.5 \mathrm{ppm}\left(J_{\mathrm{Rh}-\mathrm{P}}=140 \mathrm{~Hz}\right)$ in the ${ }^{31} \mathrm{P}$ NMR spectra and in the ${ }^{1} \mathrm{H}$ NMR spectra, a quartet/doublet pair at 5.94/1.40 ppm also appeared. These peaks gradually decreased and a new doublet peak at $28.3 \mathrm{ppm}\left(J_{\mathrm{Rh}-\mathrm{P}}=106 \mathrm{~Hz}\right)$ in the ${ }^{31} \mathbf{P}$ NMR spectra grew up and the corresponding peaks on the ${ }^{1} \mathrm{H}$ NMR were present at 4.63/0.76 ppm. The presence of two doublets of doublet peaks in the ${ }^{31} \mathrm{P}$ NMR spectrum indicated that two of the $\mathrm{PPh}_{3}$ ligands are magnetically inequivalent in cis-2d, and the small coupling constant of $15 \mathrm{~Hz}$ is attributable to the virtual coupling of magnetically inequivalent $\mathrm{PPh}_{3}$ ligands. This inequivalence arises from the diastereoisomeric nature of cis-2d, the complex having a chiral carbon, $\mathrm{C}(\mathrm{O}) \mathrm{C} * \mathrm{HClMe}$, and a cis arrangement of the phosphines. The cis-2d isomerizes to the corresponding trans-2d with chemically and magnetically equivalent phosphine ligands.

As to the structure of pentacoordinate complex of $\mathrm{Rh}$, a number of papers have been reported [12] and these may have either trigonal bipyramidal (TBP) or square pyramidal (SP) structure. Interestingly for a TBP structure, the coupling constant $J_{\mathrm{Rh}-\mathrm{P}}$ for the equatorial phosphite is larger than that for the corresponding axial phosphite, for example, $\left[\mathrm{Rh}\left(\mathrm{P}(\mathrm{OMe})_{3}\right)_{5}\right] \mathrm{BPh}_{4}, J_{\mathrm{Rh}-\mathrm{P}(\mathrm{e})}=206, \mathrm{~Hz}, J_{\mathrm{Rh}-\mathrm{P}(\mathrm{a})}=143$ $\mathrm{Hz}$ [13]. A similar dependence of $J_{\mathrm{Rh}-\mathrm{P}}$ has been observed in the trigonal bipyramidal complex, $\mathrm{RhCl}\left(\mathrm{Ph}_{2} \mathrm{POCH}_{2} \mathrm{CH}=\mathrm{CH}_{2}\right)_{2}$ and other related complexes in which one phosphorus occupies an equatorial and the other an axial position. A TBP arrangement has been suggested for $\mathrm{RhCl}_{2}\left(\mathrm{PhCH}_{2} \mathrm{CH}_{2} \mathrm{CO}\right)\left(\mathrm{PPh}_{3}\right)_{2}$, on the basis of preliminary $\mathrm{X}$-ray data; two phosphines occupy the axial positions.

For a 5-coordinated acyl complex the transformation between TBP and TP is probably a fast equilibration process. For acetyl chloride, there is an equilibrium between trans-acyl complex and alkyl complex with the major stable species being 


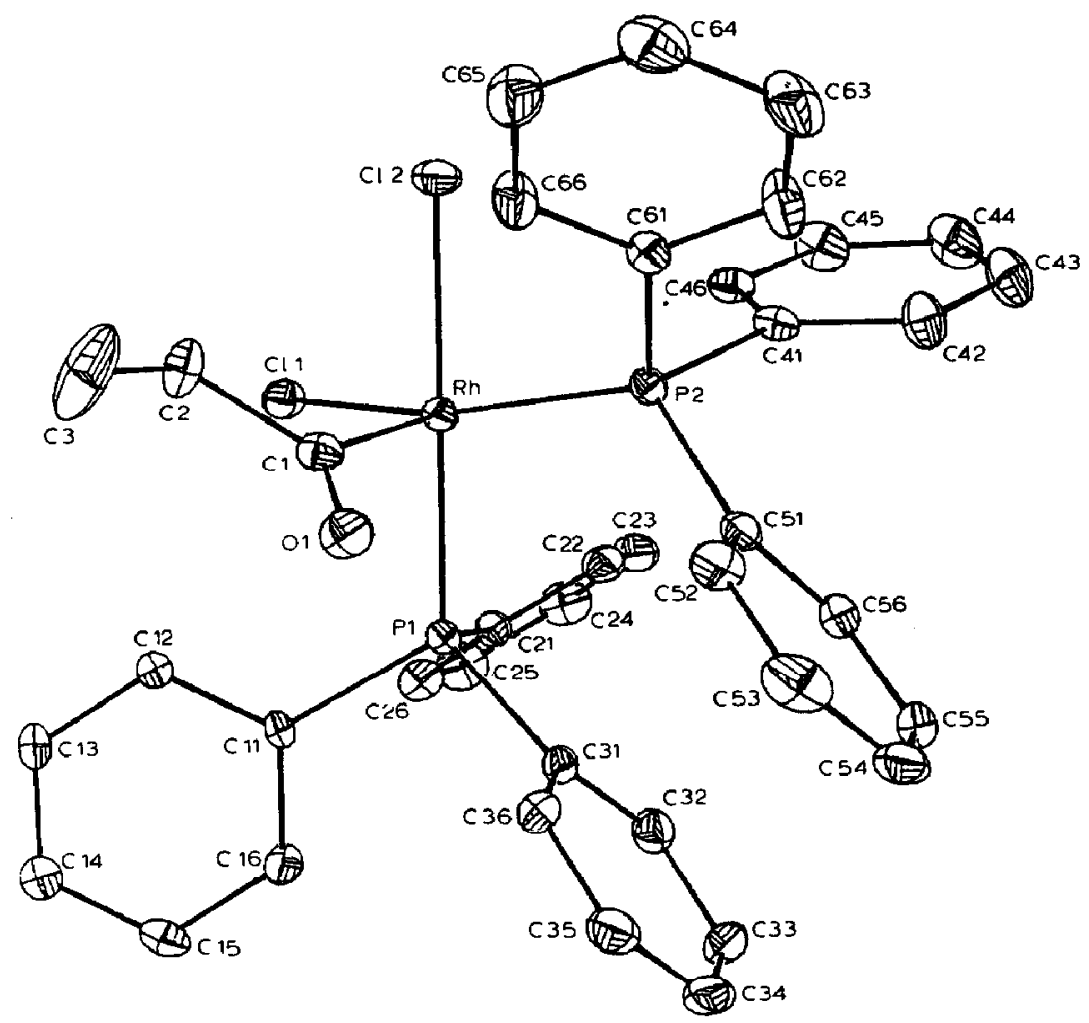

Fig. 1. ORTEP drawing of $\left.c i s-\mathrm{RhCl}_{2}\left(\mathrm{PPh}_{3}\right)_{2} 9 \mathrm{COEt}\right)$, cis-2c. Hydrogen atoms are omitted for clarity.

the trans-acyl complex. However, under similar reaction conditions, the ethyl complex, $\mathrm{Cl}_{2} \mathrm{Rh}(\mathrm{CO})\left(\mathrm{CH}_{2} \mathrm{CH}_{3}\right)\left(\mathrm{PPh}_{3}\right)_{2}$, was not observed in our experiment but $\mathrm{Cl}_{2} \mathrm{Rh}(\mathrm{CO})\left(\mathrm{CH}_{2} \mathrm{Cl}\right)\left(\mathrm{PPh}_{3}\right)_{2}$ was readily formed. Thus electronic effects play an important role in the alkyl migration reaction. The electron-withdrawing group enhances the ability to undergo the acyl-to-alkyl rearrangement. This conclusion is consistent with a report by Stille, who carried out decarbonylations on a number of benzoyl complexes, $\left(p-\mathrm{YC}_{6} \mathrm{H}_{4} \mathrm{CO}\right) \mathrm{Cl}_{2} \mathrm{Rh}\left(\mathrm{PPh}_{3}\right)_{2}\left(\mathrm{Y}=\mathrm{OCH}_{3}, \mathrm{H}, \mathrm{Cl}, \mathrm{NO}_{2}\right)$ [13]. The first-order rate constant of alkyl migration was found to fall in the order $\mathrm{Y}=\mathrm{NO}_{2}>\mathrm{Cl}>\mathrm{H}>\mathrm{OCH}_{3}$.

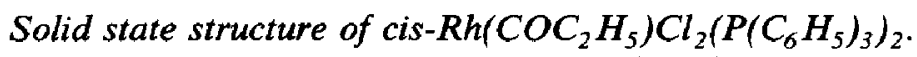

The crystal structure of $c i s-2 \mathrm{c}$ contains discrete monomeric molecules. An ORTEP perspective drawing along with the labeling scheme is shown in Figure 1. The coordination geometry around the metal is square pyramidal with the propionyl group occupying the apical position. A view of the SP coordination geometry is presented in Figure 2. Atomic coordinates and isotropic thermal parameters are given in Table 3 and important intramolecular distances and angles for the structure are given in Table 4. The orientation of the acyl group is such that the acyl oxygen points between the two phosphine ligands which might minimize nonbonded repulsions with the $\mathrm{PPh}_{3}$ ligand and thus restricting rotation about the $\mathrm{Rh}$-acyl bond. For a low spin, pentacoordinate $d^{6}$ complex, square pyramidal geometry is expected, which is precisely what is observed here. Pignolet and co-workers [4] used 


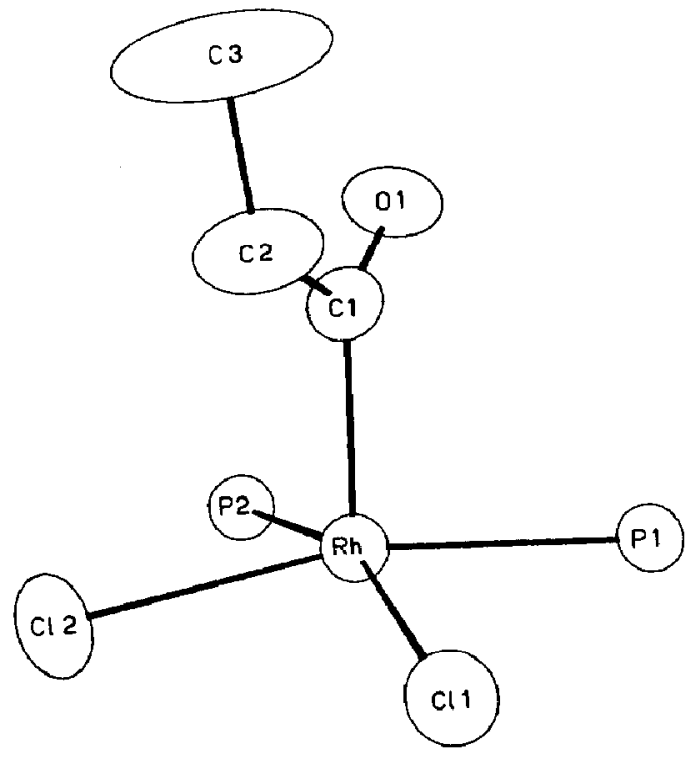

Fig. 2. Square pyramidal geometry around the Rh atom for cis-2c.

a chelating ligand to elucidate the crystal structure of $c i s-\mathrm{RhCl}_{2}(\mathrm{COPh})(\mathrm{dppe})$ and found that the $R h-C$ separation is 1.992(3) $\AA$. A list of $R h(I I I)-C \sigma$-bond distances has been tabulated by Collman et al. [14]. All values are in the range 2.05-2.26 $\AA$, except for the $1.97 \AA$ in the chelating carbene complex $\mathrm{RhI}_{3}(\mathrm{CO})(\mathrm{CPhN}(\mathrm{Me}) \mathrm{C}(\mathrm{Ph})$ -

Table 4

Selected bond distances and angles for cis-2c

\begin{tabular}{lcll}
\hline Bond distances $(\dot{A})$ & & & \\
$\mathrm{Rh}-\mathrm{Cl}(1)$ & $2.379(3)$ & $\mathrm{P}(1)-\mathrm{C}(11)$ & $1.852(9)$ \\
$\mathrm{Rh}-\mathrm{Cl}(2)$ & $2.370(3)$ & $\mathrm{P}(1)-\mathrm{C}(21)$ & $1.819(10)$ \\
$\mathrm{Rh}-\mathrm{C}(1)$ & $1.953(10)$ & $\mathrm{P}(1)-\mathrm{C}(31)$ & $1.835(10)$ \\
$\mathrm{Rh}-\mathrm{P}(1)$ & $2.320(3)$ & $\mathrm{P}(2)-\mathrm{C}(41)$ & $1.829(10)$ \\
$\mathrm{Rh}-\mathrm{P}(2)$ & $2.311(3)$ & $\mathrm{P}(2)-\mathrm{C}(51)$ & $1.805(10)$ \\
$\mathrm{C}(1)-\mathrm{C}(2)$ & $1.504(14)$ & $\mathrm{P}(2)-\mathrm{C}(61)$ & $1.848(10)$ \\
$\mathrm{C}(1)-\mathrm{O}(1)$ & $1.198(12)$ & $\mathrm{C}(3)-\mathrm{C}(2)$ & $1.409(17)$ \\
Bond angles $\left(^{\circ}\right)$ & & & \\
$\mathrm{Cl}(1)-\mathrm{Rh}-\mathrm{Cl}(2)$ & $86.07(10)$ & $\mathrm{Rh}-\mathrm{P}(1)-\mathrm{C}(11)$ & $117.8(3)$ \\
$\mathrm{Cl}(1)-\mathrm{Rh}-\mathrm{C}(1)$ & $104.0(3)$ & $\mathrm{Rh}-\mathrm{P}(1)-\mathrm{C}(21)$ & $104.4(3)$ \\
$\mathrm{Cl}(1)-\mathrm{Rh}-\mathrm{P}(1)$ & $84.11(10)$ & $\mathrm{Rh}-\mathrm{P}(1)-\mathrm{C}(31)$ & $123.5(3)$ \\
$\mathrm{Cl}(1)-\mathrm{Rh}-\mathrm{P}(2)$ & $161.24(10)$ & $\mathrm{C}(11)-\mathrm{P}(1)-\mathrm{C}(21)$ & $105.7(5)$ \\
$\mathrm{Cl}(2)-\mathrm{Rh}-\mathrm{C}(1)$ & $99.6(3)$ & $\mathrm{C}(11)-\mathrm{P}(1)-\mathrm{C}(31)$ & $99.7(4)$ \\
$\mathrm{Cl}(2)-\mathrm{Rh}-\mathrm{P}(1)$ & $166.69(11)$ & $\mathrm{C}(21)-\mathrm{P}(1)-\mathrm{C}(31)$ & $104.1(4)$ \\
$\mathrm{Cl}(2)-\mathrm{Rh}-\mathrm{P}(2)$ & $83.40(10)$ & $\mathrm{Rh}-\mathrm{P}(2)-\mathrm{C}(41)$ & $107.0(3)$ \\
$\mathrm{C}(1)-\mathrm{Rh}-\mathrm{P}(1)$ & $91.5(3)$ & $\mathrm{Rh}-\mathrm{P}(2)-\mathrm{C}(51)$ & $122.2(3)$ \\
$\mathrm{C}(1)-\mathrm{Rh}-\mathrm{P}(2)$ & $93.0(3)$ & $\mathrm{Rh}-\mathrm{P}(2)-\mathrm{C}(61)$ & $116.7(3)$ \\
$\mathrm{P}(1)-\mathrm{Rh}-\mathrm{P}(2)$ & $103.47(10)$ & $\mathrm{C}(41)-\mathrm{P}(2)-\mathrm{C}(51)$ & $104.6(5)$ \\
$\mathrm{Rh}-\mathrm{C}(1)-\mathrm{C}(2)$ & $112.4(7)$ & $\mathrm{C}(41)-\mathrm{P}(2)-\mathrm{C}(61)$ & $105.3(5)$ \\
$\mathrm{Rh}-\mathrm{C}(1)-\mathrm{O}(1)$ & $126.3(8)$ & $\mathrm{C}(51)-\mathrm{P}(2)-\mathrm{C}(61)$ & $99.4(5)$ \\
$(2)-\mathrm{C}(1)-\mathrm{O}(1)$ & $121.3(9)$ & & \\
& & &
\end{tabular}


NMe) where metal $\rightarrow$ ligand back bonding undoubtedly occurs. In the present structure, the very short $\mathrm{Rh}$-acyl carbon bond distance is $1.95(1) \AA$, even shorter than that of the $\mathbf{R h}$-carbene separation. Such a short separation could be rationalized in terms of two factors, namely (i) the decrease of the covalent radius of carbon on going from the $\mathrm{sp}^{3}$ hybridization of alkyls to the $\mathrm{sp}^{2}$ hybridization of an acyl, and (ii) a back-bonding interaction between a filled $d_{\pi}$ orbital of the $\mathrm{Rh}$ (III) center and a vacant $\pi^{\star}$ orbital of the acyl ligand. [4]. Other parameters within the structure are more or less as expected. The $R \mathbf{R}-\mathbf{P}$ bond lengths average $2.316(3) \AA$ and agree with typical $\mathrm{Rh}(\mathrm{III})$-phosphine values reported. Experiments in progress are directed at determining the $\mathrm{Rh}-\mathrm{C}$ separation for the trans-isomer.

\section{Acknowledgements}

We thank the National Science Council of the Republic of China for financial support.

\section{References}

1 (a) J.P. Collman and L.S. Hegedus, J.R. Norton and R.G. Finke, Principles and Applications of Organotransition Metal Chemistry, publisher(s)?, 1987, p 768. (b) H.M. Walborsky and L.E. Allen, J. Am. Chem. Soc., 93, (1971) 5465. (c) H.M. Walborsky and L.E. Allen, Tetrahedron Lett., (1970) 823.

2 (a) K. Ohno and J. Tsuji, J. Am. Chem. Soc., 90 (1968) 99. (b) J. Tsuji and K. Ohno, J. Am. Chem. Soc., 88 (1966) 3452. (c) J. Tsuji and K. Ohno, Tetrahedron Lett., (1966) 4713.

3 L.H. Pignolet, Homogeneous Catalysis with Phosphine Complexes, Plenum Press, New York, 1983, p 343-375.

4 M.F. McGuiggan, D.H. Doughty, L.H. Pignolet, J. Organomet. Chem., 185 (1980) 241.

5 D.L. Egglestone, M.C. Baird, C.J.L. Lock and G. Turner, J. Chem. Soc., Dalton Trans., (1977) 1576.

6 K.S.Y. Lau, Y. Becker, F. Haung, N. Baenziger and J.K. Stille, J. Am. Chem. Soc., 99 (1977) 5664.

7 J.A. Osborn, F.H. Jardine, J.F. Young and G. Wilkinson, J. Chem. Soc. (A), (1966) 1711.

8 International Tables for X-ray Crystallography, Kynoch Press, Birmingham, 1974, Tables $2.2 B$ and 2.3.1.

9 (a) J. Halpern and C.S. Wong., J. Chem. Soc., Chem. Commun., (1973) 629. (b) J. Halpern, Inorg. Chim. Acta., 50 (1981) 11. (c) F.H. Jardine, Prog. Inorg. Chem. 28, (1982) 64 (d) D.A. Wink and P.C. Ford, J. Am. Chem. Snc., 109 (1987) 436.

10 D.A. Slak D.L. Egglestone and M.C. Baird, J. Organomet. Chem., 146 (1978) 71.

11 M.C. Baird, J.T. Mague, J.A. Osborn and G. Wilkinson, J. Chem. Soc. (A), (1967) 1347.

12 P.S. Pregosin and R.W. Kunz, P. and C NMR of Transition Metal Phosphine Complexes, SpringerVerlag, New York, 1979, p. 38.

13 J.K. Stille and M.T. Regan, J. Am. Chem. Soc., 96 (1974) 1508.

14 (a) J.A. Evans, D.R. Russell, A. Bright, B.L. Shaw, J. Chem. Soc., Chem. Commun., (1971) 841. (b) P.C. Appleton, H.C. Clark, L.E. Manzer, Coord. Chem. Rev., 10 (1973) 335. (c) J.P. Collman, P.A. Christian, S. Current, P. Denisevich, T.R. Halbert, E.R. Schmittou, K.O. Hodgson, Inorg. Chem., 15 (1976) 223.

15 P.B. Hitchcock, M.F. Lappert, G.M. McLaughlin, A.J. Oliver, J. Chem. Soc., Dalton Trans., (1974) 68. 